\title{
Determination of pectin methylesterase activity in commercial pectinases and study of the inactivation kinetics through two potentiometric procedures
}

\author{
Determinação da atividade da pectina metilesterase de pectinases comerciais e \\ estudo da inativação por dois procedimentos potenciométricos
}

Samantha Lemke GONZALEZ ${ }^{1}$, Neiva Deliberali ROSSO ${ }^{1 *}$

\begin{abstract}
Pectinases are enzymes that degrade pectic substances and are widely used in juice and fruit beverages to improve the quality of the process. The objective of this study was to determine the optimum $\mathrm{pH}$ and temperature of two samples of commercial pectinases and propose an alternative procedure to determine the residual activity comparing the data with those of the traditional procedure. The pectin methylesterase (PME) activity in Pectinex $100 \mathrm{~L}$ Plus and Panzyn Clears was determined by potentiometry. The reaction consisted of $5.00 \mathrm{mg}^{\mathrm{mL}} \mathrm{m}^{-1}$ apple pectin, $0.100 \mathrm{~mol} . \mathrm{L}^{-1} \mathrm{NaCl}$, and $50 \mu \mathrm{L}$ enzyme to a total volume of $30 \mathrm{~mL}$. The pectin reaction in the presence of PME in all experiments revealed a first order kinetics. The PME in the two enzyme preparations showed higher activity at pH 4.0 to 4.5 and temperature of $45^{\circ} \mathrm{C}$. From the results of both procedures $\Delta \mathrm{V}_{\mathrm{NaOH}} / \Delta \mathrm{t}$ and $\Delta \mathrm{pH} / \Delta \mathrm{t}$, it was concluded that the inactivation of PME occurred at $75{ }^{\circ} \mathrm{C}$. The results obtained from the ratio $\Delta \mathrm{pH} / \Delta \mathrm{t}$ showed good correlation with those obtained from the ratio $\Delta \mathrm{V}_{\mathrm{NaOH}} / \Delta \mathrm{t}$. In the reaction accompanied by the ratio $\Delta \mathrm{pH} / \Delta \mathrm{t}$, the release of $\mathrm{H}_{3} \mathrm{O}^{+}$occurred in the real time reaction.
\end{abstract}

Keywords: pectin; pectin methylesterase; potentiometric procedure; residual activity.

\section{Resumo}

As pectinases são enzimas que degradam substâncias pécticas, são amplamente utilizadas pelas indústrias de sucos e bebidas para melhorar a qualidade do processo. O objetivo deste trabalho consistiu em determinar o $\mathrm{pH}$ e a temperatura ótima de duas amostras de pectinases industriais, propor um procedimento alternativo para determinar a atividade residual e comparar os resultados com aqueles do procedimento tradicional. A atividade da PME na Pectinex 100 L Plus e Panzym Clears foi determinada por potenciometria. A reação consistiu de 5,00 mg. $\mathrm{mL}^{-1}$ de pectina de maçã, 0,100 mol. $\mathrm{L}^{-1}$ de cloreto de sódio e $50 \mu \mathrm{L}$ de enzima pectinolítica para um volume total de $30 \mathrm{~mL}$. A reação da pectina em presença da PME em todos os experimentos mostrou uma cinética de primeira ordem. A PME nas duas preparações enzimáticas apresentou maior atividade em pH 4,0 a 4,5 a $45^{\circ} \mathrm{C}$. A partir dos resultados de ambos os procedimentos $\mathrm{V}_{\mathrm{NaOH}} / \Delta \mathrm{t}_{\text {tempo }}$ e $\Delta \mathrm{pH} / \Delta \mathrm{t}_{\text {tempo }}$, concluiu-se que a inativação da PME ocorreu na temperatura de $75^{\circ} \mathrm{C}$. Os resultados obtidos por $\Delta \mathrm{pH} / \Delta \mathrm{t}_{\text {tempo }}$ apresentaram boa correlação com aqueles por $\Delta \mathrm{V}_{\mathrm{NaOH}} / \Delta \mathrm{t}_{\text {tempo }}$, na reação acompanhada por $\Delta \mathrm{pH} / \Delta \mathrm{t}_{\text {tempo }}$ tem-se a liberação de $\mathrm{H}_{3} \mathrm{O}^{+}$no tempo real da reação.

Palavras-chave: pectina; pectina metilesterase; procedimentos potenciométricos; atividade residual.

\section{Introduction}

Pectinolityc enzymes or pectinases can be divided into three large groups, protopectinases, depolymerases, and esterases. Protopectinases degrade the insoluble protopectin and give rise to highly polymerized soluble pectin. The depolimerases catalyze hydrolysis of a $(1 \rightarrow 4)$ glycosidic linkages in pectic acid. The esterases catalyze the pectin de-esterification by the removal of metoxyl ester group. In the esterases group, the pectin methylesterase (PME; EC: 3.1.1.11) is found. Pectinases are found in plants, bacteria, and fungi. The PME present in plants and bacteria has optimum $\mathrm{pH}$ that ranges between 6 and 8 , whereas the optimum $\mathrm{pH}$ of that produced by fungi is around 4 and 6, (BENEN et al., 2003; JAYANI; SAXENA; GUPTA, 2005). Commercial pectinases are produced by microbiologically safe strains from Aspergullus sp. They are widely used by the juice and fruit beverage industry because they favor clarification and for making filtration easier resulting in a better performance of the process (ALKORTA et al., 1998).

Ceci and Lozano (1998) determined the PME activity in the commercial enzyme samples Rohapect D5S and Pectinol. They observed that the optimum $\mathrm{pH}$ for the enzyme was 4.6. Mutlu et al. (1999) studied the Ultra SP-L Pectinex kinetic parameters, monitored the viscosity change of the pectin solution by enzyme action, and determined the PME activity at $\mathrm{pH} 3.5$ at $35^{\circ} \mathrm{C}$. Commercial pectinases are also used for the extraction of orange juice (KASHYAP et al., 2001) because they promote an increase in sugar extraction as well as soluble solutions, increase productivity, and decrease juice viscosity. Duvetter et al. (2005) studied the inactivation kinetics of purified PME from Aspergillus aculeatus. The enzyme inactivation occurred at the temperature range of 46 to $56^{\circ} \mathrm{C}$

Received 10/6/2009

Accepted 14/2/2010 (004240)

${ }^{1}$ Laboratório L11 de Pesquisa Química Analítica e Inorgânica, Departamento de Química, Mestrado em Ciência e Tecnologia de Alimentos, Universidade Estadual de Ponta Grossa - UEPG, Av. Carlos Cavalcanti, 4748, CEP 84030-900, Ponta Grossa - PR, Brasil, E-mail: ndrosso@uepg.br

${ }^{*}$ Corresponding author 
and followed a first order kinetics. They also observed that there was no decrease in the activity after pressurization at $700 \mathrm{MPa}$ for an hour at $25^{\circ} \mathrm{C}$. Grassin et al. (2005) studied the commercial pectinases composition used in apple maceration. They verified that the sample composition depends on the Aspergillus sp. employed in the enzymatic preparation, fermentation conditions, and methods used in recovering and purifying the enzyme. The authors found that there is enzymatic diversity in the products called pectinases, in which the PME concentration and polygalacturonase predominates. Nikolic' and Mojovic (2007) studied the Aspergillus niger (FPG) polygalacturonase, Aspergillus niger pectin methylesterase (FPE), and the tomato pectin methylesterase (PPE) action in the Budimka (Pyrus malus L.) apple pectin hydrolysis. The reaction was conducted by the individual and combined action of FPG, FPE, and PPE enzymes, the optimum $\mathrm{pH}$ values verified, 4.5 , 3.5 , and 6.5 , and the optimum temperature of 40,45 , and in the $40-45^{\circ} \mathrm{C}$ range, respectively. It was also observed that the FPE enzyme presented higher efficiency in the pectin hydrolysis when compared to PPE.

Fraeye et al. (2007) extracted and purified strawberry pectin, characterized and compared its molecular weight, the garu esterification, and the composition of sugar with those of apple pectin. Both pectins were treated with Aspergillus Aculeatus PME in order to determine the speed of deesterification at 0.1 to $500 \mathrm{Mpa}$ pressure and temperatures of 20 to $60^{\circ} \mathrm{C}$. The A. aculeatus PME optimum activity observed was at 200 to $300 \mathrm{Mpa}$ pressure at $45-55^{\circ} \mathrm{C}$.

Sampedro, Rodrigo and Hendrickx (2008) determined the PME inactivation kinetics via treatment in combined conditions of high pressure and temperature in an orange juice and milk beverage. They observed that for complete inactivation, a treatment at $90{ }^{\circ} \mathrm{C}$ for one minute or one at $700 \mathrm{MPa}$ at $55{ }^{\circ} \mathrm{C}$ for two minutes was necessary. Wilinska et al. (2008) studied the exogenous Aspergillus niger PME stability and inactivation kinetics in fruit juice, apple and blueberries juice, at the temperature range $52-66^{\circ} \mathrm{C}$. They observed that the enzyme activity decreased with the increase in temperature, and that the juice composition caused a considerable difference in the enzymatic susceptibility to the thermal treatment. They also verified that the exogenous PME inactivation reaction followed a first order kinetics. Plaza et al. (2008) studied the influence of $\mathrm{pH}$, ionic strength and also the presence of salt and polyols in the recombinant Aspergillus aculeatus PME thermal stability. The authors observed that the PME was thermostable at $50{ }^{\circ} \mathrm{C}$ in the presence of $\mathrm{NaCl}$ at $\mathrm{pH} 5.0$, and that the polyols presented higher protection effect for the enzyme than the sugars. They also found that $\mathrm{pH}$ and ionic strength were important parameters for the enzymatic stability.

Pectic substances constitute a complex of heteropolysaccharides of high molecular weight, 25 to $360 \mathrm{kDa}$. These are present in most vegetable tissues, mainly in ripe fruit. They are the main component in the middle lamella among cells such as calcium and magnesium pectate (JAYANI; SAXENA; GUPTA, 2005; SCHELLER et al., 2007). The degree of esterification of pectin influences the gelling properties, gel pectins with a high degree of esterification at $\mathrm{pH}$ around 3.0 , and in the presence of sugar (ROLIN, 1993; FU; RAO, 1999, 2001). Pectin with low esterification degree forms gel in the presence of calcium ions in a wide $\mathrm{pH}$ range with or without sugar. Pectin with high methoxylation content can be treated with alkaline reagents or enzymes such as PME. The role of PME is to demethoxylate the galacturonic chain to produce low methoxylation content pectin.

PME acts in the pectin catalyzing the $\mathrm{C}$-O bond hydrolysis of the methoxyl-ester groups forming methanol and converting pectin into pectate (Figure 1). During the pectate formation, there is a decrease in $\mathrm{pH}$ indicating $\mathrm{H}_{3} \mathrm{O}^{+}$release. For the hydrolysis of each mmol of the ester group, the release of one $\mathrm{H}_{3} \mathrm{O}^{+}$mmol occurs. Thus, the reaction can be followed by a potentiometric system accurately calibrated according to Martell and Motekaitis (1992). Studies aiming at elucidating the PME action and inactivation conditions are frequent issues in the research in this area.

The objective of this work consisted of determining the optimum $\mathrm{pH}$ and temperature of two commercial pectinases samples by proposing an alternative procedure to determine the residual activity and comparing data with those obtained with the traditional procedure.

\section{Materials and methods}

Industrial enzymatic preparations of Pectinex $100 \mathrm{~L}$ Plus and Panzym Clears were supplied by Novozymes. These enzymatic preparations consisted of a mixture of pectinolytic enzymes with the predominance of poligalacturonase, pectinaliase and PME produced by Aspergillus sp. submerse fermentation. The samples were within the shelf life.

\subsection{PME activity through $\mathrm{NaOH}$ volume variation}

The PME activity was determined by titrimetry, which consists of quantifying free carboxyl groups formed by the enzyme action. The experimental system consisted of a double walled glass cell connected to a thermostatized bath (Microquimica, MQBTC 99-20) with $\pm 0.1^{\circ} \mathrm{C}$ precision and a B474 Micronal pHmeter equipped with a combined electrode, which was calibrated daily with buffer solutions, $\mathrm{pH} 4.0$ and 7.0 (Merck). The experiments were carried out with controlled addition of $\mathrm{CO}_{2}$ free sodium hydroxide, 0.05 mol.L-1 (Merck) using a digital micro-burette (Denver instrument-Titrator 280), $0.01 \mathrm{~mL}$ precision. The reaction consisted of $0.150 \mathrm{~g}$ apple

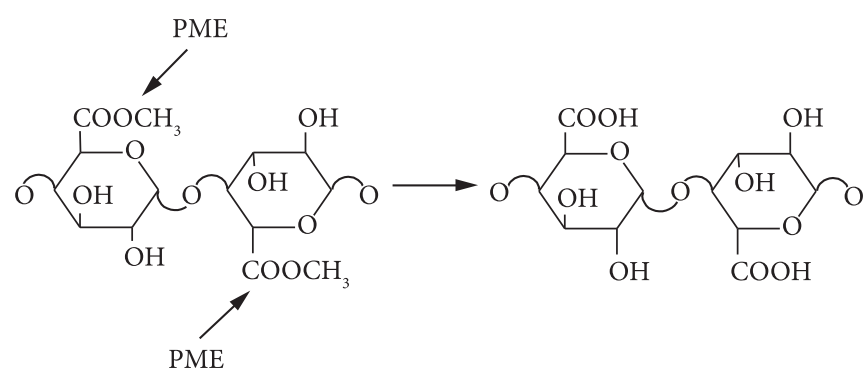

Figure 1. Site in which the PME acts in the pectic substances. Source: Jayani, Saxena and Gupta (2005). 
pectin, $5.00 \mathrm{mg} \cdot \mathrm{mL}^{-1}$ (Herbstreith and Fox, high methoxylation degree), 0.100 mol. $^{-1}$ sodium chloride (Merck), and the volume completed with ultra-pure water up to $30 \mathrm{~mL}$. After dissolving the components, $50 \mu \mathrm{L}$ of commercial pectinolytic enzyme was added. Temperature and $\mathrm{pH}$ were kept constant, and the reaction was carefully controlled in terms of $\mathrm{NaOH}$ consumption to keep the $\mathrm{pH}$ constant. According to Fachin et al. (2002), the PME activity is proportional to the rate of $\mathrm{NaOH}\left(\Delta \mathrm{V}_{\mathrm{NaOH}} / \Delta \mathrm{t}\right)$ and can be expressed in units, $U$, defined as micromoles of acid produced per minute. In this study, the unit used to express the PME activity was mmol acid produced per second.

The influence of $\mathrm{pH}$ and temperature in the Pectinex $100 \mathrm{~L}$ Plus and Panzyn Clears commercial pectinases activity was verified. The $\mathrm{pH}$ effect on the enzyme activity was determined with the values $3.0 ; 3.5 ; 4.0 ; 4.25 ; 4.5 ; 5.0$, and 5.5 , keeping the reaction temperature constant at $45 \pm 0.1^{\circ} \mathrm{C}$. The effect of temperature on the demethoxylation reaction was verified with the values of $25-35-45-55-65-75^{\circ} \mathrm{C}$, keeping the $\mathrm{pH}$ constant at 4.0. All experiments were performed in duplicate, and the activity obtained from the average values was represented on a graph.

To determine the residual activity of PME in the Pectinex 100 L Plus and Panzym Clears, samples of these preparations were placed in polyethylene bottles properly sealed and subjected to temperatures of $45,50,55,60,65,70$, and $75^{\circ} \mathrm{C}$ for 10,20 , and 30 minutes at each temperature. Next, $50 \mu \mathrm{L}$ of the enzyme were added to the reaction system, $5 \mathrm{mg} \cdot \mathrm{mL}^{-1}$ pectin, $0.100 \mathrm{~mol} \mathrm{~L}^{-1} \mathrm{NaCl}$ and the volume was completed with ultrapure water up to $30 \mathrm{~mL}$. The reaction was then conducted at $45^{\circ} \mathrm{C}$ and $\mathrm{pH} 4.0$.

\section{Determination of $P M E$ activity through $p H$ variation}

The PME activity for the commercial pectinase samples was also determined following the $\mathrm{pH}$ variation as a function of the time $\Delta \mathrm{pH} / \Delta \mathrm{t}$ since the PME action on the pectin substrate produces $\mathrm{H}_{3} \mathrm{O}^{+}$ions and methanol. The $\mathrm{H}_{3} \mathrm{O}^{+}$ions can be directly quantified with a system containing a combined electrode, previously calibrated, connected to a pHmeter. The system and the conditions described above in section 2.1, were used; however, this procedure made possible to monitor the reaction without $\mathrm{NaOH}$ addition, which reduces the occurrence of errors.

Through the $\mathrm{pH}$ variation, the Pectinex $100 \mathrm{~L}$ Plus and Panzym Clears pectinases' activity was determined at $25{ }^{\circ} \mathrm{C}$ and $\mathrm{pH}$ 4.5. The residual activity was also determined with this procedure for both pectinase samples at $45,50,55,60,65$, 70 , and $75^{\circ} \mathrm{C}$ for 10,20 , and 30 minutes of exposure at each temperature, as previously reported.

\section{Results and discussion}

\subsection{Determination of optimum $\mathrm{pH}$, temperature, and residual activity of Pectinex $100 \mathrm{~L}$ plus and panzym clears}

Figure 2 represents the influence of $\mathrm{pH}$ on the PME activity of a Pectinex $100 \mathrm{~L}$ Plus commercial pectinase sample keeping the temperature constant at $45^{\circ} \mathrm{C}$. The optimum $\mathrm{pH}$ observed for Panzym Clears was of 4.0, value at which the PME maximum activity occurred. It was verified that the $\mathrm{pH}$ influenced the enzyme activity because for values above or below $\mathrm{pH} 4.0$ there was a decrease in the enzyme activity. For the Panzym Clears commercial pectinase sample at constant temperature $45^{\circ} \mathrm{C}$, it was also observed that the maximum PME activity was at $\mathrm{pH}$ 4.0. These data is in agreement with those reported by Duvetter et al. (2005), Dinu et al. (2007) for commercial pectinase samples obtained from Aspergillus aculeatus and niger.

Figure 3 shows the temperature influence on the PME activity of Pectinex $100 \mathrm{~L}$ Plus keeping the $\mathrm{pH}$ constant at 4.0. The optimum temperature observed was $45^{\circ} \mathrm{C}$, and at this value the PME activity was maximum, which is in accordance with that determined by Fraeye et al. (2007). At temperatures above or below $45^{\circ} \mathrm{C}$, the PME activity decreased. It was also verified that the maximum PME activity of Panzym Clears commercial pectinase sample at $\mathrm{pH} 4.0$ was at $45{ }^{\circ} \mathrm{C}$. This optimum temperature is in accordance with that verified by Nikolic' and Mojovic (2007) for the PME of a commercial pectinase sample produced by Aspergillus niger.

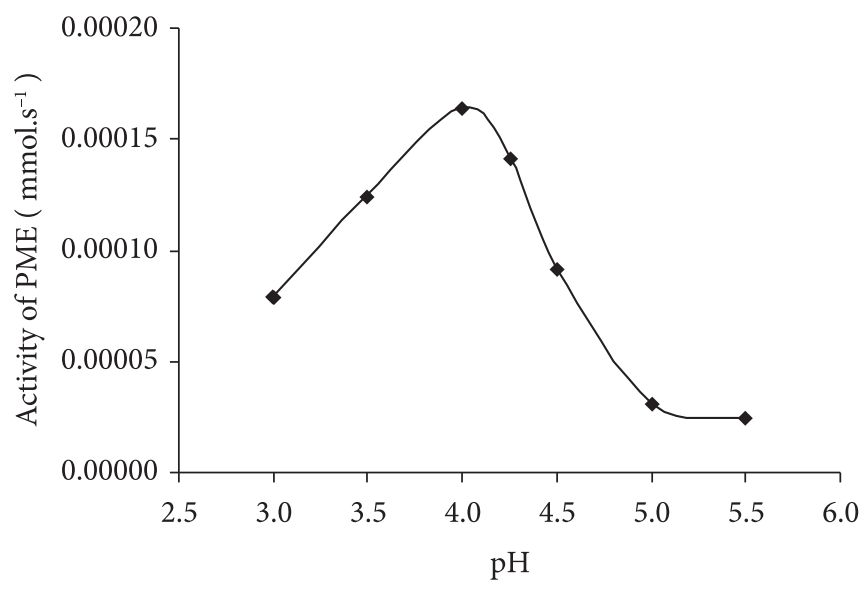

Figure 2. $\mathrm{pH}$ influence on PME activity in the Pectinex $100 \mathrm{~L}$ Plus at $45^{\circ} \mathrm{C}$. The deviation range for the measurements was from $1 \times 10^{-5}$ to $5 \times 10^{-5}$.

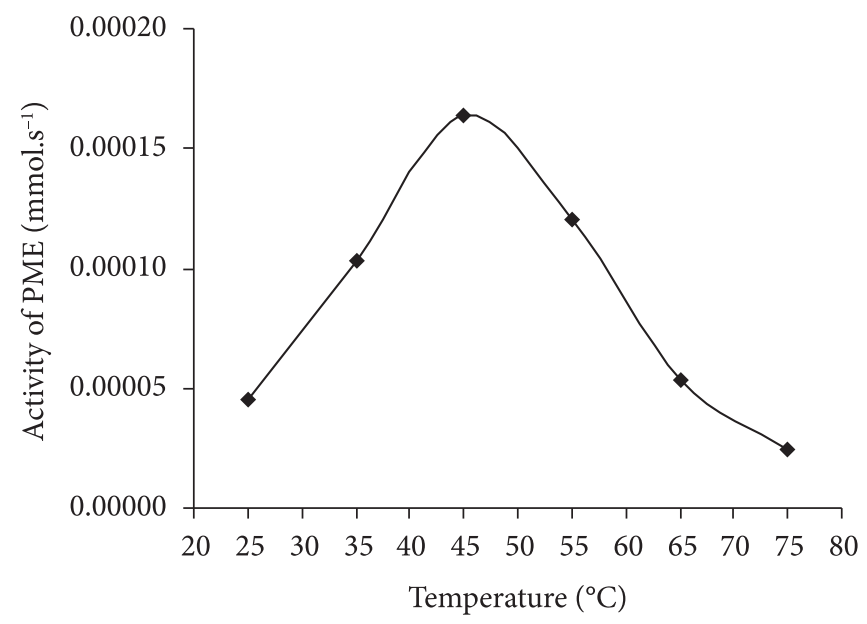

Figure 3. Temperature influence on the PME activity in the Pectinex $100 \mathrm{~L}$ Plus at $\mathrm{pH}$ 4.0. The deviation range for the measurements was from $1 \times 10^{-5}$ to $5 \times 10^{-5}$. 
Figure 4 shows the thermal stability of a Pectinex $100 \mathrm{~L}$ Plus commercial pectinase sample. It was observed that with the increase in temperature, the PME inactivation occurred. The maximum PME activity was observed with the treatment at $45^{\circ} \mathrm{C}$ for 10,20 , and 30 minutes. However, for the treatment at $75^{\circ} \mathrm{C}$, the PME residual activity dropped to $2.49 \%$ for 10 minutes of exposure, and after 20 minutes, the complete inactivation occurred. For the Panzym Clears commercial pectinase sample in thermal treatment at $45^{\circ} \mathrm{C}$ for 10,20 , and 30 minutes, the PME activity remained at the maximum value. The complete inactivation occurred at $75{ }^{\circ} \mathrm{C}$ during the first 10 minutes of PME exposure.

From the study of the two commercial samples, it was observed that the Panzym Clears pectinase activity was $2.62 \times 10^{-4} \mathrm{mmol} . \mathrm{s}^{-1}$, and the Pectinex $100 \mathrm{~L}$ Plus was $1.64 \times 10^{-4} \mathrm{mmol} . \mathrm{s}^{-1}$ at the $\mathrm{pH}$ value of 4.0 and temperature $45^{\circ} \mathrm{C}$. The sample Panzym Clears showed higher activity under the same conditions; therefore, it contains a higher concentration of PME. The activation energy can be considered the amount of energy necessary so that the substrate molecule reaches the activated state in the reaction system. The substrate molecule firstly absorbs energy, becoming activated, and then it converts itself into a product. The enzymatic reaction activation energy can be calculated by the Arrhenius equation and through a graphic of the PME Ln activity as a function of the reciprocal of the absolute temperature in $\mathrm{K}$ degrees.

For the calculation of the PME activation energies of Panzym Clears and Pectinex 100 L Plus pectinases, sample graphs of the Ln activity were drawn as a function of the reciprocal temperature. The temperatures applied were those in which the PME activity increases until it reaches a maximum value at the optimum temperature. The Pectinex $100 \mathrm{~L}$ Plus and Panzym Clears activation energies obtained through the data were 54.73 and $57.35 \mathrm{~kJ} \cdot \mathrm{mol}^{-1}$ with a correlation coefficient of 0.9995 and 0.9997 , respectively. A high value for the activation

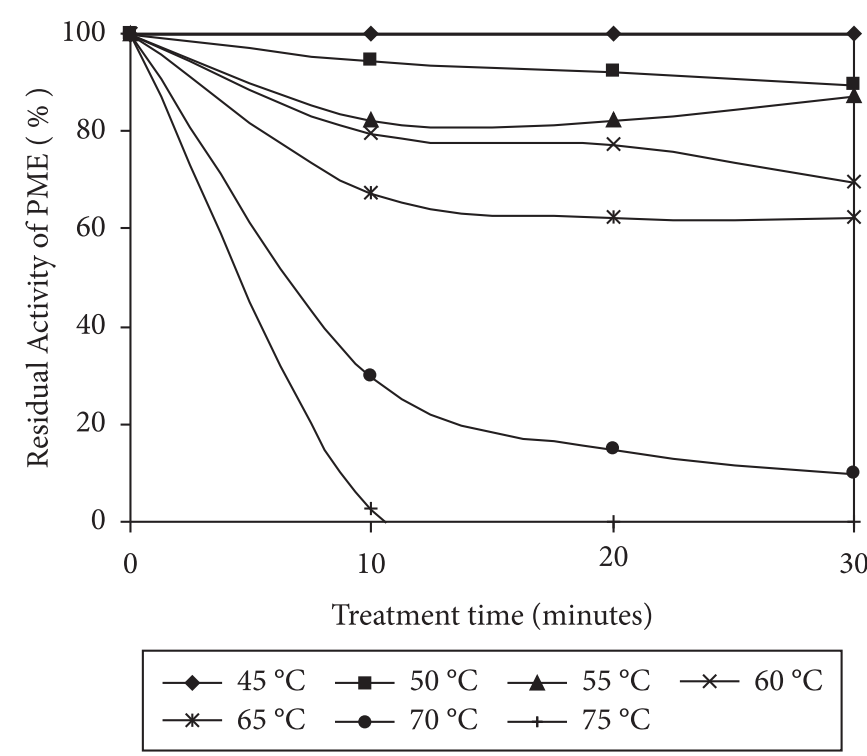

Figure 4. Pectinex $100 \mathrm{~L}$ Plus pectinase thermal stability in $5.00 \mathrm{mg} \cdot \mathrm{mL}^{-1}$ of apple pectin, $\mathrm{pH} 4.0$, at $45^{\circ} \mathrm{C}$ and $0.100 \mathrm{~mol} . \mathrm{L}^{-1} \mathrm{NaCl}$. energy means that the reaction speed increases rapidly with the increase in temperature. The values of activation energy for the samples studied are in accordance with those reported in the literature. Sarioglu et al. (2001) and Mutlu et al. (1999) determined the PME activation energy of a commercial sample, Pectinex Ultra SP-L, as $39.00 \mathrm{~kJ} . \mathrm{mol}^{-1}$.

\subsection{Determination of PME activity through the $\mathrm{pH}$ variation procedure}

In the PME reaction with pectin, the hydrolysis of the ester group with the production of one mmol methanol and one mmol ions $\mathrm{H}_{3} \mathrm{O}^{+}$occurs, which can be quantified using a potentiometric system thoroughly calibrated. The PME activity in both pectinase commercial samples was determined at $25^{\circ} \mathrm{C}$ with initial $\mathrm{pH}$ of 4.5 . The reaction was monitored for 10 minutes registering the $\mathrm{pH}$ value as a function of the time. A sharp $\mathrm{pH}$ decrease at the beginning of the reaction was observed, as the PME acted on the substrate. For the calculation of the activity, the $\mathrm{pH}$ variation in the first minutes of the reaction was used, Equation 1.

$\Delta \mathrm{pH}=\mathrm{pH}_{\mathrm{f}}-\mathrm{pH}_{0}$

$\mathrm{pH}_{0}$ : initial $\mathrm{pH}$, enzyme free; and

$\mathrm{pH}_{\mathrm{f}}$ : final $\mathrm{pH}$ after enzyme addition at each interval of the reaction.

From the system $\mathrm{pH}$ the hydrogenionic concentration of the reaction is directly obtained, Equation 2.

$\mathrm{pH}=-\log \left[\mathrm{H}^{+}\right]$

Then, the $\mathrm{H}^{+}$concentration is obtained, Equation 3.

$\left[\mathrm{H}^{+}\right]=10^{(-\mathrm{pH})}$

For the PME activity calculation; the hydrogenionic concentration variation was used, $\Delta\left[\mathrm{H}^{+}\right]$, Equation 4 .

$\Delta\left[\mathrm{H}^{+}\right]=\left[\mathrm{H}^{+}\right]_{\mathrm{f}}-\left[\mathrm{H}^{+}\right]_{0}$

$\left[\mathrm{H}^{+}\right]_{0}$ : Enzyme free hydrogenionic concentration; and

$\left[\mathrm{H}^{+}\right]_{\mathrm{f}}:$ Hydrogenionic concentration after enzyme action at each interval of the reaction.

The final and initial $\mathrm{pH}$ values were converted into hydrogenionic concentrations and substituted in Equation (4) in order to obtain a $\Delta\left[\mathrm{H}^{+}\right]$at each different reaction interval, Table 1. The reaction follows a first order kinetics, and the PME activity is the straight line angular coefficient.

Table 1. $\mathrm{pH}$ convertion into hydrogenionic concentration $\left[\mathrm{H}^{+}\right]$as a function of time and the hydrogenionic concentration variation, $\Delta\left[\mathrm{H}^{+}\right]$, which corresponds to each time interval in the Pectinex $100 \mathrm{~L}$ Plus PME activity determination at $25^{\circ} \mathrm{C}$ and $\mathrm{pH} 4.5$.

\begin{tabular}{cccc}
\hline Time $(\mathrm{s})$ & $\mathrm{pH}$ & {$\left[\mathrm{H}^{+}\right](\mathrm{mol})$} & $\Delta\left[\mathrm{H}^{+}\right](\mathrm{mol})$ \\
\hline 0 & 4.50 & $3.162 \times 10^{-5}$ & - \\
60 & 4.28 & $5.248 \times 10^{-5}$ & $2.086 \times 10^{-5}$ \\
120 & 4.19 & $6.456 \times 10^{-5}$ & $1.208 \times 10^{-5}$ \\
180 & 4.15 & $7.079 \times 10^{-5}$ & $0.623 \times 10^{-5}$ \\
\hline
\end{tabular}


Figure 5 shows the reaction behavior as a function of $\Delta\left[\mathrm{H}^{+}\right]$ (mol), as a function of time (s), it was observed that the reaction follows a first order kinetics. As can be seen in Figure 5, it is possible to observe a linear response, Equation 5, between the hydrogenionic concentration variation in function of time. The activity of PME in the commercial Pectinex $100 \mathrm{~L}$ Plus sample was the angular coefficient, that is, $1.219 \times 10^{-7} \mathrm{~mol} . \mathrm{s}^{-1}$.

$\Delta\left[\mathrm{H}^{+}\right]=2.768 \times 10^{-5}-1.219 \times 10^{-7} \times \mathrm{t}(\mathrm{s})$

All experiments for the determination of PME activity were performed in duplicate: the activity value according to the second experiment was $1.095 \times 10^{-7} \mathrm{~mol} . \mathrm{s}^{-1}$ and the average between the activities was $1.157 \times 10^{-4} \mathrm{mmol} . \mathrm{s}^{-1}$ for the Pectinex $100 \mathrm{~L}$ Plus PME sample at $25^{\circ} \mathrm{C}$ and $\mathrm{pH} 4.5$.

Table 2 shows the PME activity in both commercial samples through the $\Delta \mathrm{pH}$ and $\Delta \mathrm{V}_{\mathrm{NaOH}}$ procedure at $25^{\circ} \mathrm{C}$ and $\mathrm{pH} 4.5$. Good agreement between the PME activity values determined by the $\Delta \mathrm{V}_{\mathrm{NaOH}}$ and $\Delta \mathrm{pH}$ procedures was observed. The activity values determined in both procedures show that the Panzym Clears pectinase presented higher activity thus presenting higher PME concentration.

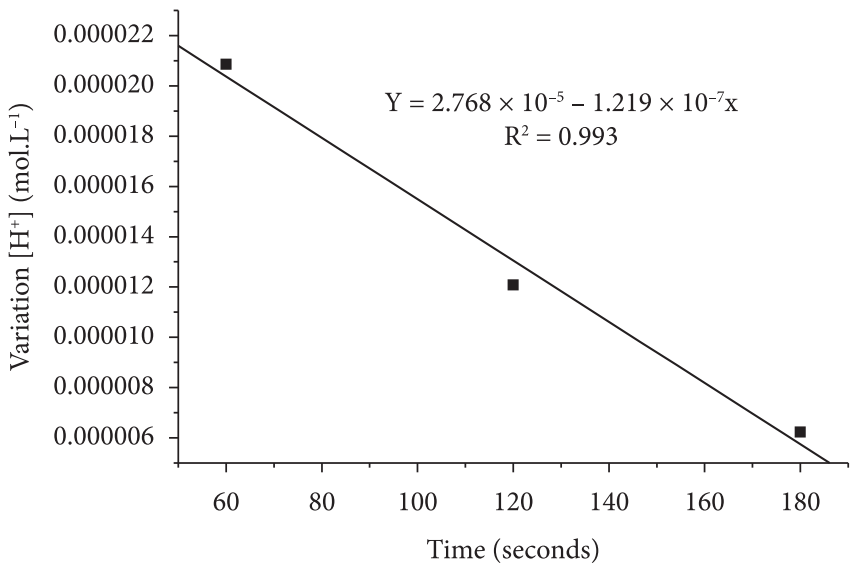

Figure 5. Pectinex $100 \mathrm{~L}$ Plus PME reaction kinetics with $5.00 \mathrm{mg} \cdot \mathrm{L}^{-1}$ pectin at $25^{\circ} \mathrm{C}$ and $\mathrm{pH} 4.5$.

Table 2. PME activity in both commercial samples through the $\Delta \mathrm{pH}$ and $\Delta \mathrm{V}_{\mathrm{NaOH}}$ procedure at $25^{\circ} \mathrm{C}$ and $\mathrm{pH} 4.5$.

\begin{tabular}{ccc}
\hline Pectinase commercial sample & \multicolumn{2}{c}{ PME activity $\left(\mathrm{mmol.s}^{-1}\right)$} \\
\hline Panzym Clears & $\Delta \mathrm{pH}$ & $\Delta \mathrm{V}_{\mathrm{NaOH}}$ \\
Pectinex 100 L Plus & $1.291 \times 10^{-4}$ & $1.080 \times 10^{-4}$ \\
\hline
\end{tabular}

The Pectinex 100 L Plus and the Panzym Clears PME residual activity was also determined by the $\mathrm{pH}$ variation procedure. The Pectinex $100 \mathrm{~L}$ Plus PME residual activity data is shown in Figure 6. It can be seen that with the thermal treatment at $45^{\circ} \mathrm{C}$ for 10,20 , and 30 minutes, the activity remained at the maximum value. This is due to the fact that the PME is at its optimum temperature. The PME complete inactivation occurred at $75^{\circ} \mathrm{C}$ for 20 minutes. It was observed that temperature and time of exposure influence the PME residual activity. For the Panzym Clears pectinase, the PME activity remained at the maximum value in the treatment at $45^{\circ} \mathrm{C}$ for 10,20 , and 30 minutes of exposure; the complete inactivation occurred at $75^{\circ} \mathrm{C}$ for 10 minutes

The Pectinex 100 L Plus PME thermal treatment data obtained through the $\mathrm{NaOH}$ volume variation procedure (Figure 4) show good correlation with those obtained through $\mathrm{pH}$ variation procedure (Figure 6). Table 3 summarizes the percentage values of PME residual activity obtained through both procedures. It can be seen that in both methods the treatment at $45^{\circ} \mathrm{C}$ for 10,20 , and 30 minutes of exposure the activity remained in the maximum value. Complete inactivation occurred at $75{ }^{\circ} \mathrm{C}$ for 20 minutes of exposure. Therefore, more reliable quantitative information was obtained through the $\Delta \mathrm{pH} / \Delta \mathrm{t}$ procedure compared to the traditional procedure, $\Delta \mathrm{V}_{\mathrm{NaOH}} / \Delta \mathrm{t}$.

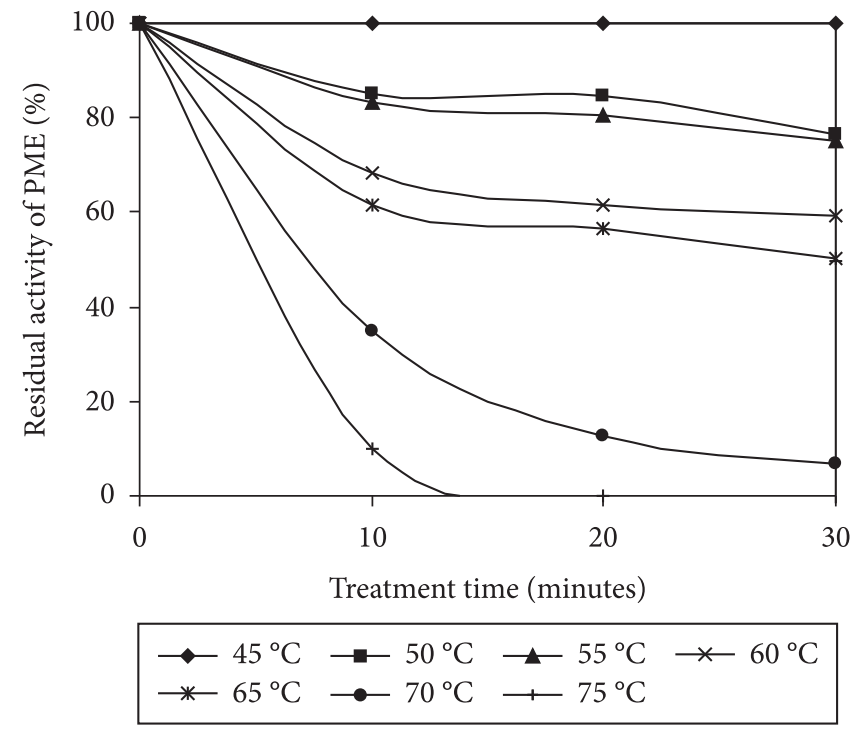

Figure 6. Pectinex $100 \mathrm{~L}$ Plus PME residual activity in $5.00 \mathrm{mg} \cdot \mathrm{mL}^{-1}$ of apple pectin, $\mathrm{pH} 4.0$, at $45^{\circ} \mathrm{C}$ and $0.100 \mathrm{~mol} . \mathrm{L}^{-1} \mathrm{NaCl}$ through $\Delta \mathrm{pH}$.

Table 3. Residual activity of Pectinex 100 L Plus, from both procedures in \%.

\begin{tabular}{|c|c|c|c|c|c|c|c|c|c|c|}
\hline \multirow{2}{*}{$\begin{array}{c}\text { Temperature }\left({ }^{\circ} \mathrm{C}\right) \\
\text { Procedimentos: } \\
\boldsymbol{A}=\Delta \mathrm{V}_{\mathrm{NaOH}} / \Delta \mathrm{t} \\
\boldsymbol{B}=\Delta \mathrm{pH} / \Delta \mathrm{t} \\
\end{array}$} & \multicolumn{2}{|c|}{45} & \multicolumn{2}{|c|}{55} & \multicolumn{2}{|c|}{65} & \multicolumn{2}{|c|}{70} & \multicolumn{2}{|c|}{75} \\
\hline & $A$ & $B$ & $A$ & B & $A$ & $B$ & $A$ & & $A$ & $B$ \\
\hline \multicolumn{11}{|l|}{ Time (min) } \\
\hline 10 & 100 & 100 & 84 & 83.4 & 67.4 & 64.1 & 29.9 & 34.6 & 2.49 & 6.90 \\
\hline 20 & 100 & 100 & 84 & 82.1 & 62.3 & 60.0 & 15.0 & 12.6 & 0.00 & 0.00 \\
\hline 30 & 100 & 100 & 84 & 75.1 & 62.3 & 56.3 & 10.0 & 6.8 & 0.00 & 0.00 \\
\hline
\end{tabular}




\section{Conclusions}

The pectin reaction in the presence of PME in all experiments revealed a first order kinetics. It was also observed that the PME in both enzymatic preparations, Pectinex $100 \mathrm{~L}$ Plus and Panzym Clears, was the most active at $\mathrm{pH}$ range of 4.0 to 4.5 . It was concluded that the enzyme in both pectinases presented the highest activity at $45^{\circ} \mathrm{C}$, and that the Panzym Clears sample contains the highest PME concentration. From the results of both procedures on the pectinase samples, $\Delta \mathrm{V}_{\mathrm{NaOH}} / \Delta \mathrm{t}$ and $\Delta \mathrm{pH} / \Delta \mathrm{t}$, it was concluded that inactivation occurred at $75^{\circ} \mathrm{C}$ for 10 minutes of exposure. The results obtained through the $\mathrm{pH}$ variation procedure as a function of time presented good correlation with the traditional method. The reaction followed by $\mathrm{pH}$ variation as a function of time makes unnecessary the use of a number of reagents and relatively high cost materials. Through this procedure, there is the release of $\mathrm{H}_{3} \mathrm{O}^{+}$at the real reaction time thus reaching the most precise activity values.

\section{Acknowledgements}

The authors are grateful to the financial support of CAPES and Fundação Araucária.

\section{References}

ALKORTA, I. et al. Industrial applications of pectic enzymes: a review. Process Biochemistry, v. 33, n. 1, p. 21-28, 1998. http://dx.doi. org/10.1016/S0032-9592(97)00046-0

BENEN, J. A. E.; VAN ALEBEEK, G. J. W. M; VORAGEN, A. G. J. Handbook of food enzymology. New York: Basel, 2003.

CECI, L.; LOZANO, J. Determination of enzymatic activities of commercial pectinases for the clarification of apple juice. Food Chemistry, v. 61, p. 237-241, 1998. http://dx.doi.org/10.1016/ S0308-8146(97)00088-5

DINU, D. et al. Enzymes with new biochemical properties in the pectinolytic complex produced by Aspergillus niger MIUG 16. Journal of Biotechnology, v. 131, p. 128-137, 2007. http://dx.doi. org/10.1016/j.jbiotec.2007.06.005

DUVETTER, T. et al. Aspergillus aculeatus pectin methylesterase: study of the inactivation by temperature and pressure and the inhibition by pectin methylesterase inhibitor. Enzyme and Microbial Technology, v. 36, p. 385-390, 2005. http://dx.doi.org/10.1016/j. enzmictec.2004.01.014

FACHIN, D. et al. Comparative Study of the Inactivation Kinetics of Pectinmethylesterase in Tomato Juice and Purified Form. Biotechnology, v. 18, p. 739-744, 2002.

FU, J. T.; RAO, M. A. The influence of sucrose and sorbitol on gel-sol transition of low-methoxyl pectin $+\mathrm{Ca}{ }^{2+}$ gels. Food Hydrocolloids, v. 13, p. 371-380, 1999. http://dx.doi.org/10.1016/ S0268-005X(99)00022-3
FU, J. T.; RAO, M. A. Rheology and structure development during gelation of low-methoxyl pectin gels: the effect of sucrose. Food Hydrocolloids, v. 15, p. 93-100, 2001. http://dx.doi.org/10.1016/ S0268-005X(00)00056-4

FRAEYE, I. et al. Comparison of enzymatic de-esterification of strawberry and apple pectin at elevated pressure by fungal pectinmethylesterase. Innovative Food Science \& Emerging Technologies, v. 8, p. 93-101, 2007. http://dx.doi.org/10.1016/j. ifset.2006.07.004

GRASSIN, C. et al. Enzymatic composition of commercial pectinases in use in the fruit juice industry. Fruit Processing, p. 130-135, 2005.

JAYANI, R. S.; SAXENA, S.; GUPTA, R. Microbial pectinolytic enzymes: A review. Process Biochemistry, v. 40, p. 2931-2944, 2005. http://dx.doi.org/10.1016/j.procbio.2005.03.026

KASHYAP, D. R. et al. Applications of pectinases in the commercial sector: a review. Bioresource Technology, v. 77, p. 215-227, 2001. http://dx.doi.org/10.1016/S0960-8524(00)00118-8

MARTELL, A. E.; MOTEKAITIS, R. J. The Determination and Use of Stability Constants. New York: VCH Publishers, 1992.

MUTLU, M. et al. The use of commercial pectinase in fruit juice industry. Part I: viscosimetric determination of enzyme activity. Journal of Food Engineering, v. 41, p. 147-150, 1999. http://dx.doi. org/10.1016/S0260-8774(99)00088-6

NIKOLIC', M. V.; MOJOVIC, L. Hydrolysis of apple pectin by the coordinated activity of pectic enzymes. Food Chemistry, v. 101, p. 1-9, 2007. http://dx.doi.org/10.1016/j.foodchem.2005.12.053

PLAZA, L. et al. Influence of environmental conditions on thermal stability of recombinant Aspergillus aculeatus pectinmethylesterase. Food Chemistry, v. 111, p. 912-920, 2008. http://dx.doi. org/10.1016/j.foodchem.2008.05.004

ROLIN, C. Pectins. In: WHISTLER, R. L.; BEMILLER, J. N. Industrial Gums: Polysaccharides and Their Derivates. 3th ed. San Diego: Academic Press, 1993. p. 257-293.

SARIOGLU, K. et al. The use of commercial pectinase in fruit juice industry. Part I: determination of the kinetic behaviour of immobilized commercial pectinase. Journal of Food Engineering, v. 47, p. 271-274, 2001. http://dx.doi.org/10.1016/S02608774(00)00124-2

SAMPEDRO, F.; RODRIGO, D.; HENDRICKX, M. Inactivation kinetics of pectin methyl esterase under combined thermal-high pressure treatment in an orange juice-milk beverage. Journal of Food Engineering, v. 86, p. 133-139, 2008. http://dx.doi. org/10.1016/j.jfoodeng.2007.09.019

SCHELLER, H. V. et al. Biosynthesis of pectin. Physiologia Plantarum, v. 129 , p. $283-295,2007$. http://dx.doi.org/10.1111/j.13993054.2006.00834.x

WILINSKA, A. et al. Thermal inactivation of exogenous pectin methylesterase in apple and cloudberry juices. Journal of Food Engineering, v. 85, p. 459-46, 2008. http://dx.doi.org/10.1016/j. jfoodeng.2007.08.009 